ISSN No. 0974-035X

An indexed refereed \& peer-reviewed journal of higher education

Towards Excellence

UGC-HUMAN RESOURCE DEVELOPMENT CENTRE

Gujarat University, Ahmedabad-380009, Gujarat, India

\title{
THE PERILS OF BEING A SPY: A CRITICAL ANALYSIS OF CASINO ROYALE (2006) THEME SONG YOU KNOW MY NAME
}

\section{Prof. Dr. Chetan N. Trivedi \\ Rohal S. Raval}

\begin{abstract}
The present article offers a critical analysis of the Theme Song You Know My Name that accompanies and serves as the title song for the $21^{\text {st }}$ James Bond film Casino Royale (2006). A reboot of the Bond franchise, Casino is credited with introducing more physical and psychological realism to the series compared to previous instalments. As such, the song paints a picture of the constant perils that characterize the life of a secret agent along with the personal sacrifices (s)he needs to make in service of country and the greater good. Moreover, it raises pertinent questions regarding the psychological effects of taking lives, whether in self-defense or for safety and security of the country. The themes of death, killing, failure, betrayal, and the need of sacrifices on part of the agent are explored through an interesting blending or interweaving of 'voices' of past and prospective secret agents along with warnings from Fate and Bond's own reply. The analysis goes on to reveal the depth and richness of meaning in lyrics which at first sight or hearing might be considered devoid of emotional or psychological depth and realism.
\end{abstract}

Keywords: Casino Royale. Chris Cornell and David Arnold. James Bond. Secret Service. Theme Song.

\section{Introduction}


Towards Excellence: An Indexed, Refereed \& Peer Reviewed Journal of Higher Education / Prof.Dr. Chetan Trivedi \& Rohal Raval / Page 148-156

A commercially successful and critically acclaimed as well as derided franchise running since 1962, the James Bond series of films and its titular character owe their genesis to Ian Fleming (1908 - 1964), the British writer whose novels and short-stories featuring the fictional spy have entertained millions of readers and spawned equally entertaining adaptations. At the same time, several films in the series have had original screenplays with only Fleming's central character(s) being retained. Each film, beginning with From Russia With Love (1963) is accompanied by a theme song, often immediately placed after the opening sequence, and serves to foreshadow, reflect, and/or comment upon events in the movie.

The present article intends to offer a critical analysis of the Theme Song that accompanies Casino Royale (2006), the $21^{\text {st }}$ instalment in the James Bond franchise. The creative credits of the song are listed below

Table 01: Song Credits for You Know My Name

\begin{tabular}{|c|c|c|c|c|}
\hline Film & Theme Song & Singer(s)/Performer(s) & Songwriter(s) & Composer \\
\hline Casino & You Know & Chris Cornell & Chris Cornell & David \\
Royale & My Name & & and David & Arnold \\
& & & Arnold & \\
\hline
\end{tabular}

Though every Bond Theme Song 'works' equally well even when not heard in context of the movies, their true depth and meaning can be better gleaned by keeping Bond and the films' storyline at the centre. As such, the article will refer to the broader plot outline of Casino as and when necessary. A cursory glance at the song immediately reveals the central themes and concerns in Bond's line of work - the possibility and risk of death in the line of duty, killing (the enemy/enemies of State), and betrayal.

Following Pierce Brosnan's final outing as Bond in Die Another Day (2002), the series was rebooted with Daniel Craig taking over the role of the iconic British secret agent. [Interestingly, March, 2021. VOL.13. ISSUE NO. 1 https://hrdc.gujaratuniversity.ac.in/Publication $\quad$ Page | 149 
the first film to present James Bond on screen, Dr. No (1962) was not an adaptation of Fleming's first novel to feature the character of Bond: Casino Royale (1953)]. According to David G. Allan,

One of refreshing aspects of Craig's reboot is the realism it brought the franchise [sic] -- at least in comparison to the cheesy jokes, comic book villains and baffling plans of world domination in earlier films. More in keeping with the plot lines of the Fleming novels, this new cinema Bond is a flawed (if stylish) hero who is severely brutalized, both physically and emotionally. (Allan)

\section{You Know My Name: A Critical Analysis}

The series reboot, an adaptation of Fleming's 1953 novel Casino Royale, begins with Bond having been newly promoted to 00 status. As such, the title of the theme song - You Know My Name - plays upon prior appearances of the character (both in novels and films) signaling spectator familiarity with the character known for his dangerous exploits and seductive powers. As Jeremy Strong writes, “Chris Cornell's theme song for the film reminds viewers, 'You know my name'; a refrain which served to introduce a new actor into the role while promising audiences that the movie would combine familiar elements with a degree of innovation" (Introduction 3).

In the film's opening sequence, Bond (Daniel Craig) reveals to Prague section chief Dryden (Malcolm Sinclair), who was selling confidential intelligence, that he had killed Dryden's contact Fisher (Daud Shah), before proceeding to eliminate Dryden himself. The sequence provides the backstory of how Bond earned his 00 status - one requirement being making two kills. Although Bond's expressions remain passive when Dryden taunts him about feeling remorse or guilt on killing Fisher, somewhere deep down the burden of guilt must be borne by one's conscience - even though those killed were enemies of the country - cloaked as it might be with the famed license to kill (00:00:30 - 00:03:30). Unlike previous films, where Bond's 
charisma, charm, flamboyance, and wit (even in life-threatening circumstances) were highlighted, reducing the character's emotional depth, Craig's Bond is more realistic - perhaps even contemplative on the inside - as the opening lines of the song reveals: "If you take a life do you know what you'll give? / Odds are you want like what it is" (Cornell and Arnold).

Interestingly, the song could also be read as a fine blend of the 'voices' of previous (dead) 00 agents (who seem to be offering an ominous warning, educating the new Bond (and the spectators) of the precarious nature of the job), the 'voice(s)' of prospective 00 agents (marked by a bit of jealousy, perhaps) expecting to be promoted like Bond, and Fate. The former aspect of warning seems directed, apart from Bond himself, at the spectators, contrasting the flamboyance of previous instalments with the very real perils of life as a secret agent. Indeed, an exchange between M (Judi Dench), the head of MI6, and Bond early in the film makes it evident:

M. I knew it was too early to promote you.

JAMES BOND. Well, I understand 00s have a very short life expectancy . . So your mistake will be short-lived. (00:23:07 - 00:23:16)

Indeed, having killed Fisher and Dryden, the song begins with the lines mentioned above which could be read either as Bond contemplating on his actions or the 'ghosts' of dead 00 agents questioning Bond whether he is willing to give up his peace of mind, a price that he will have to "give" (Cornell and Arnold) - that is, pay - for the act of "tak[ing] a life" (Cornell and Arnold). Moreover, the voices seem to ask Bond whether he will be prepared to face the "storm" (Cornell and Arnold) of dangerous challenges when it "arrives" (Cornell and Arnold), his status as 00 being no shield, rather an invitation to "the merciless eyes of deceit" (Cornell and Arnold). Will he be able to decide between friend and foe? Indeed, as the film progresses, betrayal from those close to Bond emerges as one of the narrative threads of Casino Royale. 
One of the past 00's 'voice' taunts Bond that he has 'seen angels fall from blinding heights / But you yourself are nothing so divine / Just next in line" (Cornell and Arnold). Indeed, in the (secret) service of Queen and country, any mission could be Bond's last. When angles can "fall from blinding heights" - the reference here in part to Lucifer, whose revolt against God led to his downfall - Bond is at best a firewall or shield to protect his country from threats and at worst a killing machine who could surely die in the line of duty.

The warning to Bond is clear: his promotion to 00 status has raised the possibility of attempts on his life. Those agents desiring promotion and the coveted license to kill make it clear that Bond must "[a]rm" himself (Cornell and Arnold) - look after his own life - "because no-one else" (Cornell and Arnold) would be there to save him. Sooner or later, "[t]he odds will betray" (Cornell and Arnold) Bond and with his failure to accomplish a mission or his death a new 00 agent "will replace" (Cornell and Arnold) him, kickstarting the same cycle all over again.

Moreover, the job of a secret agent is quite unlike a regular job - boring at times, but safe. In order to keep his/her identity and nature of work a secret, they might have to sacrifice the chance of finding true love and even if they do, always be on the guards for a possible betrayal. Thus, the nature of the job is such that "it may never" let Bond have the feeling of "fulfill[ment]" (Cornell and Arnold) in terms of intimate friends or a loved one, family, children, etc. Rather, the job almost "longs to kill" (Cornell and Arnold) the agent and a grave question is put to the new 00 by both past and prospective Bonds: "Are you willing to die?" (Cornell and Arnold).

To these warnings and questions, Bond retorts that "[t]he coldest blood runs through my veins" (Cornell and Arnold), implying that any actions or killings that he might have to do will not weigh on his conscience. Further, it also suggests that because he is cold-blooded - i.e. devoid of emotion - it matters not whether he ever gets to live a normal life. Ironically, there comes a point in Casino Royale where Bond is willing to retire to spend the rest of his life with the 
woman he loves; however, things go horribly wrong and Fate pulls him back into service $(01: 49: 12-02: 18: 26)$

Even Fate seems to concur, urging Bond to reconsider the chosen life:

If you come inside things will not be the same

When you return to the night.

And if you think you've won you never saw me change

The game that we've all been playing. (Cornell and Arnold)

For instance, Bond would never be able to take a stroll during a quiet night as normal people might. Rather, there will always be the danger of enemies lurking behind to capture and torture for extracting secret information or kill him as a warning to MI6 and the government, etc. Moreover, Fate reminds Bond that it can "change / The game" (Cornell and Arnold) that he has been playing at any moment - not every time can Bond emerge lucky to survive dangerous missions and encounters. Indeed, though Bond manages to defeat Le Chiffre (Mads Mikkelsen) in a crucial, high-stakes card game, Le Chiffre captures Bond's love interest Vesper Lynd (Eva Green), intending to kill her as revenge for losing the game to Bond (01:34:57 - 01:48:43). Thus, even when Bond is not literally at the game table, he is constantly playing the game of life and death. Moreover, by the end of the film, Fate yet again "change[s] / The game" for Bond - he resigns from MI6 to lead a normal life with Vesper; however, Vesper's betrayal which it is revealed after her death she had agreed to in order to save the life of someone dear to her - ends up destroying Bond's just found peace, serenity, and love (01:57:38 - 02:12:20).

Fate or the 'voices' of Bonds past caution the newly promoted Bond to take the threats to his life seriously: "I've seen diamonds cut through harder men / Than you yourself, but if you must pretend / You may meet your end" (Cornell and Arnold). If Bond tries to shrug off every threat with a clever pun or witty remark - as previous incarnations of Bond were shown to - he might 
Towards Excellence: An Indexed, Refereed \& Peer Reviewed Journal of Higher Education /

Prof.Dr. Chetan Trivedi \& Rohal Raval / Page 148-156

soon end up dead. Indeed, by the time of Skyfall, which released in 2012, Daniel Craig had completed six years of being cast as Bond. A major theme in Skyfall is Bond's - and England's - decreasing (physical) prowess and vulnerability, to which he must come to terms with, maybe retire, before the "diamond"-like job cuts through him, figuratively and (almost) literally $(00: 27: 10$ - 00:27:19; 00:29:28 - 00:30:50; 00:36:07 - 00:36:09; 01:12:43 - 01:12:49; 01:12:53 - 01:13:51;01:40:02 - 01:40:49). As Wieland Schwanebeck notes, Skyfall "addresses the question of how much strength there is left in a grizzled hero past his prime - only to conclude with him being more powerful than ever" (169).

In order to succeed as a secret agent, the new 00 must learn to "hide" (Cornell and Arnold) his hand, as players in a card game guard their cards. He must "forget to feel" (Cornell and Arnold), avoid getting emotionally involved with anyone because loss of life, whether during missions, as collateral or revenge, is part and parcel of the job. Having decided to dedicate his life to the safety and security of his country, Bond's personal life "is gone with just a spin of the wheel" (Cornell and Arnold). Two metaphors are being invoked here: that of the roulette wheel and the spin of a revolver barrel - in both cases, loss, defeat, and death can stare one in the face at any moment.

To these grave and repeated warnings, however, Bond's refrain remains the same: that the "coldest blood" (Cornell and Arnold) runs through his veins and that all know his name. Again, this last refrain of You Know My Name, repeated seven times at the song's end, yet again relies on audience familiarity, reminding them of the famous introductory line which every actor portraying Bond has spoken on screen: The name's Bond, James Bond. Though the actors change, Bond remains. Thus, even in this more realistic take on Bond in Casino Royale, where Bond's personal and emotional needs and desires occupy a central place, betrayals and heartbreaks cannot break the man who is Bond, James Bond. 


\section{Conclusion}

A close reading of You Know My Name brings out the Eliotesque quality of the song, whereby four different 'voices' - that of past and prospective 00 agents, Fate, and Bond himself - merge or intertwine to form a coherent whole. The song brings to light the constant peril that characterizes the life of a secret agent along with the personal sacrifices (s)he needs to make in service of country and the greater good. Moreover, it raises pertinent questions regarding the psychological effects of taking lives, whether in self-defense or for safety and security of the country Thus, the major themes explored include (the risk of) death (in the line of duty), failure, killing, betrayal, and the need of sacrifices on part of the agent. The ingenious blending or interweaving of 'voices' goes on to reveal the depth and richness of meaning in lyrics which at first sight or hearing might be considered devoid of emotional or psychological depth and realism. 
Towards Excellence: An Indexed, Refereed \& Peer Reviewed Journal of Higher Education /

Prof.Dr. Chetan Trivedi \& Rohal Raval / Page 148-156

Works Cited

Allan, David G. "James Bond's Casino Royale." BBC.com, 26 October 2012, www.bbc.com/travel/story/20121024-james-bonds-casino-royale Accessed 09 January 2021.

Casino Royale. Directed by Martin Campbell, Eon Productions / Metro-Goldwyn-Mayer Pictures / Columbia Pictures, 2006.

Cornell, Chris, and David Arnold. You Know My Name. Performed by Cornell. Interscope, 2006.

---. Lyrics to You Know My Name. Genius, 2006, genius.com/Chris-cornell-you-know-myname-lyrics Accessed 02 January 2021.

Schwanebeck, Wieland. 'Licence to Replicate: Never Say Never Again (1983) as 007's Lesson in Adaptation Studies." James Bond Uncovered, edited by Jeremy Strong, Palgrave Macmillan, 2018, pp. 163-84.

Skyfall. Directed by Sam Mendes, Eon Productions / Metro-Goldwyn-Mayer Pictures / Columbia Pictures, 2012.

Strong, Jeremy. Introduction. James Bond Uncovered, edited by Strong, Palgrave Macmillan, 2018, pp. 1-22.

\section{Chetan N. Trivedi}

Vice-Chancellor, Bhakta Kavi Narsinh Mehta University (BKNMU), Junagadh Telephone: +91 9426221042; E-Mail: cntrivedi@gmail.com

\&

Rohal S. Raval

Teaching Assistant \& Research Scholar, Department of Languages

(English), Bhakta Kavi Narsinh Mehta University (BKNMU), Junagadh

Telephone: +91 9265261228; E-Mail: rraval.raval151@gmail.com 